\title{
Tobacco industry lobbying undermines public health in Asia
}

\author{
Industry targets tobacco control policies in Pakistan, India, and Laos
}

\author{
Nicholas S Hopkinson senior lecturer in respiratory medicine ${ }^{1}$, Martin McKee professor ${ }^{2}$, K Srinath \\ Reddy professor ${ }^{3}$
}

${ }^{1}$ NIHR Respiratory Biomedical Research Unit, Royal Brompton and Harefield NHS Foundation Trust and Imperial College London, London SW3 6NP, UK; ${ }^{2}$ London School of Hygiene and Tropical Medicine, London, UK; ${ }^{3}$ Public Health Foundation of India, Delhi, India

The implementation of tobacco control measures is a political choice. Although tobacco control will improve the wellbeing of the populations that governments serve, the industry spares no attempt to deter, dilute, or delay effective measures for tobacco control, be it taxation or prominent pictorial health warnings. There is troubling evidence that the tobacco industry is exerting undue influence in several Asian countries, in some cases with the complicity of governments, to thwart public health measures.

The case against tobacco is clear. An addiction that usually starts in childhood, ${ }^{1}$ smoking is predicted to kill one billion people in the 21 st century, ${ }^{2}$ with a global social burden costing an estimated $\$ 2.1 \mathrm{tn}(\mathrm{Rs} 134 \mathrm{tn} ; £ 1.4 \mathrm{tn} ; € 1.9 \mathrm{tn})$ a year. ${ }^{3}$ The means to prevent this are set out clearly in the World Health Organization's 2003 Framework Convention on Tobacco Control and the associated MPOWER policy framework (Monitor tobacco use and prevention policies, Protect people from tobacco smoke, Offer help to quit tobacco use, Warn about the dangers of tobacco, Enforce bans on tobacco advertising, promotion and sponsorship, and Raise taxes on tobacco). The countries that have implemented these measures most assiduously have seen the greatest falls in smoking rates. ${ }^{4}$

The framework convention states that there is a "fundamental and irreconcilable conflict between the tobacco industry's interests and public health policy interests." Article 5.3 of the convention binds parties to "interact with the tobacco industry only when and to the extent strictly necessary to enable them to effectively regulate the tobacco industry and tobacco products." This rule is necessary because well documented industry tactics of lobbying, bullying, and threats of litigation have delayed and continue to delay measures to reduce uptake of smoking by children and promote quitting.

\section{Delays to controls}

In October 2014 the Indian government announced plans to mandate the use of pictorial health warnings covering $85 \%$ of tobacco product packaging. This was to come into effect from 1 April 2015. However, a committee of parliamentarians that had consulted tobacco industry lobbyists successfully recommended that these plans be suspended. ${ }^{5}$ Although tobacco is estimated to account for $40 \%$ of all cancers in Indian men, ${ }^{6}$ the committee chair, Dilip Gandhi, made the extraordinary assertion that no study in India had established that tobacco causes cancer. "Whether it actually causes cancer or other diseases is subject to a study in the country. That has never happened. And the basis of our stance towards tobacco products are basically studies that have happened in a foreign setting." Senior Indian tax officials are also listed as participants in the 12th annual Asia Pacific tax forum, to be held in Delhi, and sponsored by four of the global tobacco corporations. ${ }^{7}$ Understandably, these contacts have faced vigorous opposition from the Indian public health community.

Pakistan's Ministry of National Health Services announced in February 2015 that it would introduce new regulations from the end of the following month requiring graphic images on cigarette packages to cover $85 \%$ of the packs, up from $40 \%$ previously. Following a meeting called by British American Tobacco, involving the finance minister and the minister of state for national health services regulation and coordination, a committee was constituted to review the regulations, which have now been delayed until the end of May.

Worryingly, this meeting was attended by the British high commissioner. ${ }^{8} 9$ The British government maintains that it had thought the meeting would cover only issues related to the business environment in Pakistan and not public health concerns. This complacency ignores how the tobacco industry makes use of such meetings to pursue multiple agendas. Arguments that tobacco control measures, such as price rises or packaging changes, will affect the "business environment" by facilitating smuggling or illicit tobacco sales, although a standard industry approach, have long been discredited, now with evidence from 
Asia that the industry has artificially inflated estimates of illegal trade to support its arguments. ${ }^{10}$

The government of Laos has entered into an agreement with Imperial Tobacco that maintains low levels of tax and allows the company to negotiate "from time to time, preferential taxes and duties for the importation of cigarettes and other finished tobacco products" ${ }^{11}$ Tax increases are a major tool for reducing consumption ${ }^{12}$ but this agreement means that Laos is unable to use this powerful approach.

Attempts by the tobacco industry to influence public health legislation have in the past included engaging prominent politicians such as the former UK prime minister Margaret Thatcher, ${ }^{13}$ and even attempts to develop religious arguments in favour of tobacco consumption. ${ }^{14}$ It is important to note that many Asian countries have a history of progressive tobacco control policies. ${ }^{15}$ For example, Singapore banned tobacco advertising in 1970 and Bhutan prohibits the marketing of all tobacco products. ${ }^{16}$ However, the examples of lobbying we have described highlight the importance of strengthening adherence to the framework convention. ${ }^{17}$ They also serve as a reminder of the global nature of the tobacco industry, which must not be allowed to represent itself as being in favour of "harm reduction" ${ }^{18}$ and "social responsibility"19 in one context while acting with malign ingenuity to obstruct public health in many others.

Competing interests: We have read and understood BMJ policy on declaration of interests and have no relevant interests to declare. Provenance and peer review: Commissioned; not externally peer reviewed.

1 Hopkinson NS, Lester-George A, Ormiston-Smith N, et al. Child uptake of smoking by area across the UK. Thorax 2014;69:873-5.
2 Eriksen M, Mackay J, Schluger N, et al. The tobaco atlas. World Lung Foundation, 2015. 3 McKinsey Global Institute. Overcoming obesity: an initial economic analysis, 2014. www. mckinsey.com/insights/economic studies/how the world could better fight obesity. Bilano V, Gilmour S, Moffiet T, et al. Global trends and projections for tobacco use, 1990-2025: an analysis of smoking indicators from the WHO comprehensive information systems for tobacco control. Lancet 2015;385:966-76.

5 Ghosh A. Panel defers to lobbies over science, tobacco warnings put on hold. Indian Express 2015 Apr 1. http://indianexpress.com/article/india/india-others/panel-defers-tolobbies-over-science-tobacco-warnings-put-on-hold/.

6 Mallath MK, Taylor DG, Badwe RA, et al. The growing burden of cancer in India: epidemiology and social context. Lancet Oncol 2014;15:e205-12.

7 Ghosh A. MoS, bureaucrats on guest list of tax meet funded by tobacco giants. Indian Express 2015 Apr 29. http://indianexpress.com/article/india/india-others/mos-bureaucratson-guest-list-of-tax-meet-funded-by-tobacco-giants.

8 Kmietowicz Z. Doctors demand apology for UK diplomat's involvement in Pakistan tobacco meeting. BMJ 2015;350:h1814

9 Hopkinson NS, McKee M, Britton J, et al. UK government must apologise for assisting tobacco industry lobbying in Pakistan. BMJ 2015;305:h1814.

10 Chen J, McGhee SM, Townsend J, et al. Did the tobacco industry inflate estimates of illicit cigarette consumption in Asia? An empirical analysis. Tob Control 2015 Jan 6. [Epub ahead of print.]

11 Doward J. UK cigarette firm criticised over Laos tobacco tax deal. Secondary UK cigarette firm criticised over Laos tobacco tax deal. 2014 Oct 5. www.theguardian.com/world/2014 oct/05/imperial-tobacco-laos-cigarette-tax-deal.

12 Jha P, Peto R. Global effects of smoking, of quitting, and of taxing tobacco. N Engl J Med 2014;370:60-8.

13 Petticrew M, Krishnaratne S. The fag lady, revisited: Margaret Thatcher's efforts on behalf of the tobacco industry. Public Health 2014;128:904-10.

14 Petticrew M, Lee K, Ali H, et al. "Fighting a Hurricane": tobacco industry efforts to counter the perceived threat of Islam. Am J Public Health 2015:e1-7.

15 Mackay J, Ritthiphakdee B, Reddy KS. Tobacco control in Asia. Lancet 2013;381:1581-7.

16 Bhutan forbids all tobacco sales Secondary Bhutan forbids all tobacco sales. BBC 2004 Dec 17. http://news.bbc.co.uk/1/hi/world/south asia/4012639.stm.

17 Assunta M, Dorotheo EU. SEATCA tobacco industry interference index: a tool for measuring implementation of WHO Framework Convention on Tobacco Control Article 5.3. Tob Control 2015 Apr 23.

18 Peeters S, Gilmore AB. Understanding the emergence of the tobacco industry's use of the term tobacco harm reduction in order to inform public health policy. Tob Control 2015;24:182-9.

19 Otanez M, Glantz SA. Social responsibility in tobacco production? Tobacco companies' use of green supply chains to obscure the real costs of tobacco farming. Tob Control 2011;20:403-11.

Cite this as: BMJ 2014;349:h2451

๑) BMJ Publishing Group Ltd 2015 